The Egyptian Journal of Biochemistry \& Molecular Biology VOL 34 (N.1\&2) 67- 76 December. 2016

\title{
CHEMOKINE RECEPTOR 2 (CCR2) G190A \\ POLYMORPHISM IN CHRONIC RENAL FAILURE PATIENTS REQUIRING HEMODIALYSIS
}

\author{
Nesreen G Elhelbawy ${ }^{1}$, Khaled M Elzorkany ${ }^{2}$, Amir F. Abdelatty $^{2}$ \\ ${ }^{1}$ MEDICAL BIOCHEMISTRY AND ${ }^{2}$ INTERNAL MEDICINE \\ DEPARTMENTS FACULTY OF MEDICINE, \\ MENOUFIA UNIVERSITY, EGYPT
}

Received 10/5/2016 - Accepted 28/9/2016

\begin{abstract}
End-stage renal disease is associated with the inflammatory state characterized by infiltrating macrophages/lymphocytes, a major source of chemokines. The aim of this study was to determine the association of CCR2 G190A polymorphism in patients with chronic renal failure (CRF) requiring hemodialysis. Seventy CRF patients and thirty healthy controls were enrolled in the current study; PCR-RFLP technique was used to assess the gene frequencies of CCR2 G190A. The results of the present study showed that there was a significant difference in the genotype and allele frequency distribution of CCR2 G190A in CRF patients and control subjects. A significant association was found between CCR2 G190A and CRF risk, especially, the AA genotype $(\mathrm{OR}=2.5,95 \% \mathrm{CI}=0.26-23.66)$ and $\mathrm{A}$ allele $(\mathrm{OR}=2.9,95 \%$ $\mathrm{CI}=1.14-7.3)$. The polymorphism was significantly associated with the presence of diabetes mellitus. From this study, it could be concluded that, a significant association was found between the AA genotype of CCR2 G190A polymorphism and CRF. Other chemokine polymorphisms in renal pathologies have to be further investigated with larger population based studies.
\end{abstract}

Key words: CCR2, polymorphism, PCR-RFLP, CRF.

\section{INTRODUCTION}

Inflammation is a key component of the immune response to infection, irritation or injury. Inflammation involves series of cellular events that rely on chemical messengers known as chemokines which send out signals to attract inflammatory cells, or leukocytes, to the site

* Correspondence Author (e mail: nesrin.elhelbawy@yahoo.com) 
of disease or injury (Allen et al., 2007).

Chemokines can be classified into four main subfamilies: CXC, CC, $\mathrm{CX} 3 \mathrm{C}$ and $\mathrm{XC}$ according to their amino acid composition (Sezgin et al., 2011). Chemokines exert their biological effects by interacting with $G$ protein- linked transmembrane receptors called chemokine receptors. Chemokine receptors contain 7 transmembrane domains that are found mainly on the surface of leukocytes (Murphy, 2002). After interaction with their specific chemokine ligands, chemokine receptors trigger flux of the intracellular $\mathrm{ca}^{2+}$ ions. This cause the onset of the chemotaxis process to traffic the cells to a desired location within the body (Mudroch and finn, 2000).

Chemokines receptor $2\left(\mathrm{CCR}_{2}\right)$ is the receptor for monocyte chemoattractant protein-1 MCP or CCL2 which induce monocytes to leave the blood stream and enter the surrounding tissue to become tissue macrophages (Villeda et al., 2011).

The polymorphism, CCR2-V641 (CCR2 G190A) is a transition mutation where valine 64 of CCR2 in changed to Isoleucine. CCR2 mutations have been associated with many diseases such as insulin dependent diabetes mellitus and reduced risk for sever coronary artery disease (Sezgin et al., 2011).

The pathogenic mechanisms that lead to chronic kidney diseases (CKD) converge on a common pathway that results in progressive interstitial fibrosis, peritubular capillary loss with hypoxia, and destruction of functioning nephrons because of tubular atrophy (Blanche and Rulan, 2005). Locally released chemokines contributes to the renal damage in CKD by releasing inflammatory and profibrotic factors (Anders et al., 2003). Stopping the chemokine signal is vital to resolve the inflammatory process (Anders et al., 2001).

The aim of this study was to determine the association of CCR2 G190A polymorphism in patients with chronic renal failure (CRF) requiring hemodialysis.

\section{Subjects:}

\section{MATERIALS AND METHODS}

This study was carried out at the Medical Biochemistry and Internal medicine departments, Faculty of Medicine, Menoufia University, it included 70 subjects admitted to nephrology unit and was undergoing hemodialysis for approximately $5.1 \pm 2.1$ years and the mean hemodialysis duration was $5.2 \pm 1.4$ hours per week. Thirty age 
and sex-matched healthy individuals were selected as a control group. The study was approved by ethical committee of Faculty of Medicine, Menoufia University. A written informed consent was obtained from all subjects included in the study.

\section{Methods:}

Six $\mathrm{ml}$ of venous blood was withdrawn, after 10 hours overnight fasting; $2 \mathrm{ml}$ blood was transferred into plain tube and $4 \mathrm{ml}$ into EDTA (ethylene diamine tetra acetic acid) containing tube. Colorimetric kinetic determination of serum creatinine (Fawcett and Scott, 1960)

Total genomic DNA was extracted from peripheral blood with QIA amp DNA minikit (Qiagen Hilden, Germany) and stored at $-20^{\circ} \mathrm{C}$. CCR2 G190A genotype was determined by polymerase chain reaction/ restriction fragment length polymorphism (PCR-RFLP) analysis. The PCR mixture in a $25 \mu \mathrm{L}$ final volume consisted of 12.5 $\mu \mathrm{L}$ PCR mastermix (Fermentas, St, leon- Rot, Germary), $9.5 \mu \mathrm{L} \mathrm{H}_{2} \mathrm{O}$, $1 \mu \mathrm{L}$ of each primer, and $1 \mu \mathrm{L}$ DNA. The following primers were used for amplification:forward 5'-CATTGCAATCCCAAAGACCCACTC$3^{\prime}$ and reverse 5'-TTGGTT TTGTGGGCAACATGATGG-3'.

Initial denaturation at $94^{\circ} \mathrm{C}$ for 5 minutes was followed by 33 cycles of denaturation at $94^{\circ} \mathrm{C}$ for 30 seconds, annealing at $56^{\circ} \mathrm{C}$ for 30 seconds and extension at $72^{\circ} \mathrm{C}$ for 30 seconds. Final extension step was at $72^{\circ} \mathrm{C}$ for 5 minutes. Then the amplification products were separated by electrophoresis through $2 \%$ agarose gel stained with ethidium bromide, $50 \mathrm{bp}$ Ladder was used. One band was observed (173 bp) (figure 1).

PCR product $(5 \mu \mathrm{L})$ was digested for 2 hours at $65^{\circ} \mathrm{C}$ (with $2.5 \mathrm{u}$ of BsaBI restriction endonuclease (Fermentas). Digestion products were analyzed by electrophoresis on $2 \%$ agarose. $50 \mathrm{bp}$ Ladder was used. GG genotype was identified with a single $173 \mathrm{bp}$ band. AA genotype was identified with two bands, $149 \mathrm{bp}$ and $24 \mathrm{bp}$ and those with three bands $173 \mathrm{bp}, 149 \mathrm{bp}$ and $24 \mathrm{bp}$ as GA heterozygotes (figure 2).

\section{Statistical analysis:}

Statistical analysis was performed using the SPSS 20 software package. Chi-square test is used to study association between two qualitative variables. The difference between 2 groups was performed by student's t-test for parametric variables. Odds ratio, describe the probability that people who are exposed to a certain factor will have a 
disease compared to people who are not exposed to this factor. A Pvalue of $<0.05$ was considered statistically significant.

\section{RESULTS}

The results of the present study showed no significant difference was found between control and CRF patient group regarding age and gender distribution $(\mathrm{P}>0.05)$. CRF patients had statistically significant decreased GFR, while significant increased serum creatinine level, compared with controls $(\mathrm{P}<0.05)$ (table 1$)$. There was a significant difference in the genotype and allele frequency distribution of CCR2641 in CRF patients and control subjects. The frequency of CCR2-641 genotypes $\mathrm{GG}, \mathrm{AG}$ and $\mathrm{AA}$ in patient group was $57.1 \%, 37.1 \%$ and $5.7 \%$ in comparison with $83.3 \%, 13.3 \%$ and $3.3 \%$ in control group, respectively. A significant association was found between CCR2-641 and chronic renal failure risk, specifically, the $A G$ genotype $(\mathrm{OR}=2.8$, 95\% $\mathrm{CI}=1.40-5.51)$, combined $\mathrm{AG}$ and $\mathrm{GG}$ genotypes $(\mathrm{OR}=4.1,95 \%$ $\mathrm{CI}=1.27-13.03)$ and $\mathrm{A}$ allele $(\mathrm{OR}=2.9,95 \% \mathrm{CI}=1.14-7.3)$ (table 2). The polymorphism was significantly associated with the presence of diabetes mellitus $(\mathrm{P}=0.025)$, however, the polymorphism was not significantly associated with the presence of hypertension $(\mathrm{P}=0.214)$ (table 3).

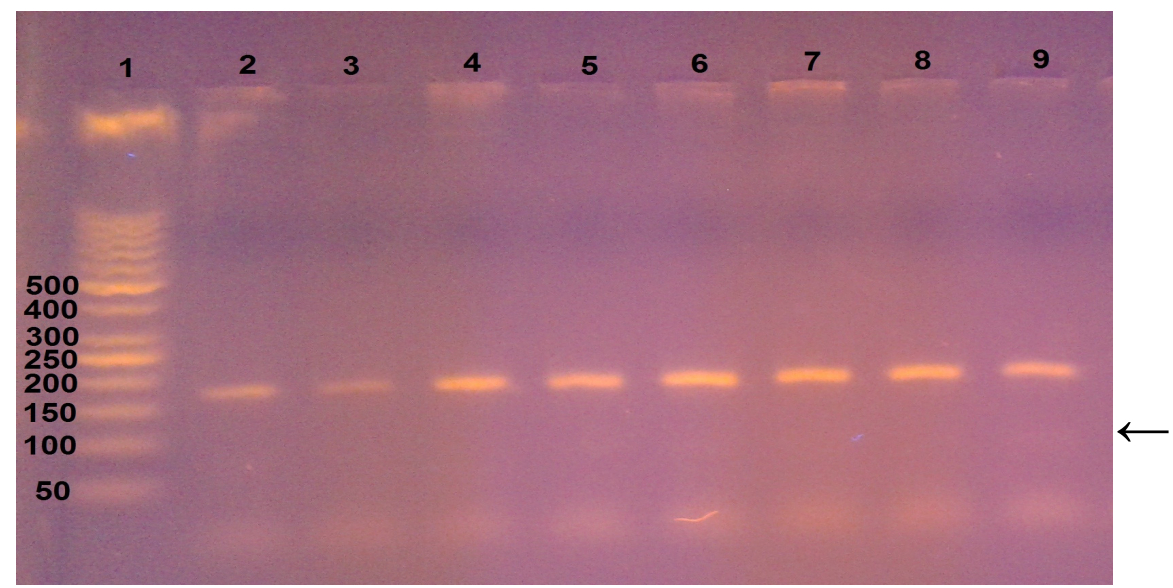

Figure (1): The agarose gel electrophoresis for CCR2 G190A gene polymorphism before digestion, represented by fragments of $173 \mathrm{bp}$ (lanes 2-9), with lane 1 represents DNA ladder (50 bp). 


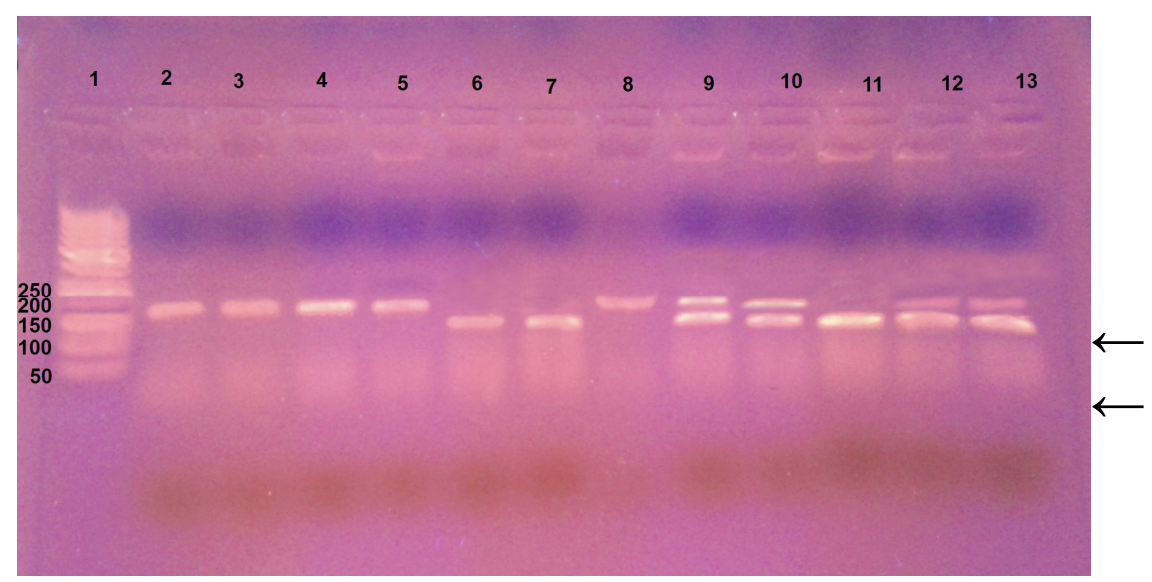

Figure (2): The agarose gel electrophoresis for CCR2 G190A gene polymorphism after digestion by BsaBI restriction enzyme, Lane 1 DNA ladder (50 bp), lanes 2, 3, 4, 5 and 8 represent GG genotype (single 173 bp band), lanes 6, 7 and 11 represent AA genotype (two bands, $149 \mathrm{bp}$ and $24 \mathrm{bp}$ ), lanes $9,10,12$ and 13 represent AG genotype (three bands $173 \mathrm{bp}, 149 \mathrm{bp}$ and $24 \mathrm{bp}$ ).

Table (1): Demographic and clinical characteristics of studied groups

\begin{tabular}{|c|c|c|}
\hline & $\begin{array}{c}\text { Patients } \\
(n=70) \\
\text { Mean } \pm \text { SD }\end{array}$ & $\begin{array}{c}\text { Controls } \\
(n=30) \\
\text { Mean } \pm \text { SD }\end{array}$ \\
\hline -Age (years) & $60.2 \pm 9.4$ & $58.9 \pm 10.7$ \\
\hline -Gender $(n, \%)$ & & \\
\hline Male & $43(61.4)$ & $19(63.3)$ \\
\hline Female & 27 (38.6) & $11(36.7)$ \\
\hline - Hemodialysis duration & $5.1 \pm 2.1$ & - \\
\hline (years) & $19(27.1)$ & - \\
\hline $\begin{array}{l}\text {-Hypertension }(\mathbf{n}, \%) \\
\text { Positive } \\
\text { Negative }\end{array}$ & $51(72.9)$ & - \\
\hline -DM (n, \%) & $24(34.3)$ & - \\
\hline Positive & $46(65.7)$ & - \\
\hline Negative & $33.8 \pm 2.2$ & $94.9 \pm 12.8 * \#$ \\
\hline -GFR $\left(\mathrm{mL} / \mathrm{min} / \mathbf{1 . 7 3} \mathrm{m}^{2}\right)$ & $3.4 \pm 0.6$ & $0.8 \pm 0.3 *^{\#}$ \\
\hline
\end{tabular}

${ }^{*} \mathrm{P}<0.001$ significant, ${ }^{*}$ test 
Table (2): Genotype and allele frequencies of CCR2641polymorphism among the two studied groups

\begin{tabular}{|l|c|c|c|}
\hline & $\begin{array}{c}\text { Patients } \\
(\mathbf{n}=70) \\
n(\%)\end{array}$ & $\begin{array}{c}\text { Controls } \\
(\mathbf{n}=30) \\
n(\%)\end{array}$ & OR (95\% CI) \\
\hline CCR2-641 & & & \\
Genotype & $40(57.1)$ & $25(83.3)^{*}$ & 1.00 \\
-GG & $26(37.1)$ & $4(13.3)$ & $4.1(1.27-13.03)$ \\
-AG & $4(5.7)$ & $1(3.3)$ & $2.5(0.26-23.66)$ \\
-AA & & & \\
Allele & $106(75.7)$ & $54(90.0) *$ & 1.00 \\
-G & $34(24.3)$ & $6(10.0)^{*}$ & $2.9(1.14-7.30)$ \\
\hline -A & & & \\
\hline
\end{tabular}

${ }^{*} \mathrm{P}<0.05$ significant, $\mathrm{OR}$ : odd's ratio

Table (3): Genotype distribution of CCR2-641polymorphism in patients regarding presence of hypertension and DM

\begin{tabular}{|l|c|c|c|}
\hline \multirow{2}{*}{} & \multicolumn{3}{|c|}{ Genotypes } \\
\cline { 2 - 4 } & GG (n=40) & AG (n=26) & AA (n=4) \\
\cline { 2 - 4 } & No (\%) & No (\%) & No (\%) \\
\hline Hypertension & $1(25)$ & $4(15.4)$ & $14(35)$ \\
\hline Diabetes mellitus & $1(25)$ & $4(15.4)$ & $19(47.5)^{* \$}$ \\
\hline
\end{tabular}

${ }^{*} \mathrm{P}<0.05$ significant ${ }^{\$}$ Chi square test

\section{DISCUSSION}

Inflammatory diseases of the kidney that progress to ESRD are characterized by accumulation of interstitial leukocytes, which are a major source of proinflammatory and profibrotic cytokines and are therefore critical in mediating fibroblast proliferation, differentiation into myofibroblasts, matrix production, and tubular damage (Eddy, 2000).

The aim of this study was to determine the association of CCR2 G190A polymorphism in patients with chronic renal failure (CRF) requiring hemodialysis.

Human CCR2 binds CCL2, CCL7, CCL8, CCL13 and CCL16 chemokines39. CCL2, an important ligand of CCR2, is expressed by tubular epithelial cells and infiltrating leukocytes in animal models of 
progressive nephropathies and renal fibrosis (Vielhauer et al., 2001). Human renal biopsy studies have confirmed such an expression pattern for CCL2 in various human kidney diseases (Anders et al., 2003). Although diabetic and vascular nephropathies are two major causes of progressive renal disease, only a few studies have been published on the role of chemokines in these disorders. An increased expression of CCL2 was reported in human diabetic nephropathy that correlated with the degree of tubulointerstitial damage and macrophage infiltration (Banba et al., 2000). In angiotensin II-dependent rat models of hypertensive nephrosclerosis, CCL2 expression was increased and was temporally and spatially related to macrophage infiltration (Okada et al, 2000).

Human studies in patients with lupus nephritis also showed that urinary CCL2 levels correlated with the extent of renal disease activity and macrophage infiltration (Wada et al., 1996). In mice lacking the CCR2 receptor, renal pathology after nephrotoxic serum was worse despite reduced glomerular macrophage infiltration, indicating that lack of CCR2 may influence other immune mechanisms besides the local cell infiltration (Bird et al, 2000). After ischemia-reperfusion renal injury the number of interstitial infiltrated macrophages was markedly smaller and the area of tubular necrosis was significantly lower in CCR2-deficient mice than that of wild-type mice (Furuichi et al., 2003).

Blocking CCR2 effectively impairs renal macrophage recruitment, which reduces renal injury in various disease models. Human renal biopsy studies that examined the spatial expression of CCR2 found similar CCR2 expression to that found in rodent disease (Segerer et al., 2000).

We have evaluated the relationship between CCR2 genotypes and disease subgroups which cause CRF in patients. No significant association were found between CCR2 genotypes and hypertension, but significantly associated with diabetes mellitus which may be an evidence of role of CCR2 genotypes in diabetic nephropathy.

Immunological and inflammatory mechanisms play a significant role in the development and progression of diabetic nephropathy (DN) (NavarroGonzalez et al., 2009). Monocytes and/or macrophages and their adherence to endothelial cells, and overexpression of proinflammatory cytokines and chemokines, contribute to the pathogenesis of DN (Nguyen et al., 2006). Deletion or blockade of C-C chemokine ligand-2 (CCL2/MCP-1) results in diminished macrophage infiltration and reduced renal injury in both type 1 and type 2 diabetes in mice (Ninichuk et al., 2008). Furthermore in humans, macrophage accumulation occurs in DN and correlates strongly with the progression of renal impairment 
(Nguyen et al.., 2006). Infiltrating macrophages release lysosomal enzymes, nitric oxide, reactive oxygen species, transforming growth factor-_, vascular endothelial growth factor, and cytokines such as TNF_. interleukin-1, and IFN__ (Tesch, 2007), which could play a pivotal role in the development and progression of $\mathrm{DN}$.

The renal-protective effect of CCR2 antagonists correlates with a significant reduction of kidney macrophage infiltration. This suggests that macrophages expressing CCR2 are pivotal during the pathogenesis of DN. These results are consistent with recent reports that CCR2 blockade preserved renal function with an associated reduction in kidney macrophage infiltration in type 2 diabetic mice (Kang et al., 2010). However, Kelly and Dominguez (2010), did not find any association between CCR2 genotypes and diabetic nephropathy.

Conclusion:

From this study, it could be concluded that, a possible significant association was found between the AA genotype of CCR2 G190A polymorphism and CRF. In order to reveal the role of chemokines in renal pathogenesis further investigations should be carried out using other chemokines and chemokine receptors in different renal diseases.

\section{REFERENCES}

Allen SJ, Crown SE and Handel TM (2007): Chemokine: receptor structure, interaction, and antagonisms. Ann Rev Immunol. 25: 787-820.

Anders HJ, Vielhauer V and Schlondorff D (2003): Chemokines and chemokine receptors are involved in the resolution or progression of renal disease. Kidney Int 63: 401-415.

Anders HJ1, Vielhauer V, Kretzler M, Cohen CD, Segerer S, Luckow B, Weller L, Gröne HJ and Schlöndorff D (2001): Chemokine and chemokine receptor expression during initiation and resolution of immune complex glomerulonephritis. J An Soc Nephrol 12 (5): 919-931.

Banba N, Nakamura T, Matsumura M, Kuroda H, Hattori Y and Kasai K (2000): Possible relationship of monocyte chemoattractant protein-1 with diabetic nephropathy. Kidney Int., 58, 684-690.

Bird JE, Giancarli MR, Kurihara T, Kowala MC, Valentine MT, Gitlitz PH, Pandya DG, French MH and Durham SK (2000): Increased severity of glomerulonephritis in $\mathrm{C}-\mathrm{C}$ chemokine receptor 2 knockout mice. Kidney Int., 57, 129-136.

Blanche Ch and Rulan S (2005): Progression in chronic kidney disease. Advance In Chronic Kidney Disease 12: 353-365.

Eddy AA (2000): Molecular basis of renal fibrosis. Pediatr. Nephrol., 15, 290-301. 
Fawcett JK and Scott JE (1960): A rapid and precise method for the determination of urea. J Clin Pathol., 13:156-159.

Furuichi K, Wada T, Iwata Y, Kitagawa K, Kobayashi K, Hashimoto H, Ishiwata Y, Asano M, Wang H, Matsushima K, Takeya M, Kuziel WA, Mukaida N and Yokoyama H (2003): CCR2 signaling contributes to ischemia-reperfusion injury in kidney.J. Am. Soc. Nephrol., 14, 2503-2515.

Kang YS, Lee MH, Song HK, Ko GJ, Kwon OS, Lim TK, Kim SH, Han SY, Han KH, Lee JE, Han JY, Kim HK and Cha DR (2010): CCR2 antagonism improves insulin resistance, lipid metabolism, and diabetic nephropathy in type 2 diabetic mice. Kidney Int 78: 883-894.

Kelly KJ and Dominguez JH (2010): Rapid progression of diabetic nephropathy is linked to inflammation and episodes of acute renal failure. Am J Nephrol 32: 469-475.

Mudroch C and finn A (2000): Chemokine receptors and their role in inflammation and infectious diseases. Blood 95(10): 3032-3043.

Murphy PM (2002): International union of pharmacology. XXX. Update on chemokine receptor nomenclature. Pharmacol Rev. 54(2): 227-229.

Navarro-Gonzalez JF, Jarque A, Muros M, Mora C and Garcia J (2009): Tumor necrosis factor-alpha as a therapeutic target for diabetic nephropathy. Cytokine Growth Factor Rev 20: 165-173.

Nguyen D, Ping F, Mu W, Hill P, Atkins RC and Chadban SJ (2006): Macrophage accumulation in human progressive diabetic nephropathy. Nephrology (Carlton) 11: 226-231.

Ninichuk V, Clauss S, Kulkarni O, Schmid H, Segerer S, Radomska E, Eulberg D, Buchner K, Selve N, Klussmann S and Anders HJ (2008): Late onset of $\mathrm{Ccl} 2$ blockade with the Spiegelmer mNOX-E36-3=PEG prevents glomerulosclerosis and improves glomerular filtration rate in $\mathrm{db} / \mathrm{db}$ mice. Am J Pathol 172: 628-637.

Okada H, Moriwaki K, Kalluri R, Imai H, Ban S, Takahama M and Suzuki H (2000): Inhibition of monocyte chemoattractant protein-1 expression in tubular epithelium attenuates tubulointerstitial alteration in rat Goodpasture syndrome. Kidney Int., 57, 927-936.

Segerer S., Cui Y., Hudkins K.L., Goodpaster T., Eitner F., Mack M., Schlondorff D. and Alpers C. E. (2000): Expression of the chemokine monocyte chemoattractant protein-1 and its receptor chemokine receptor 2 in human crescentic glomerulonephritis. J. Am. Soc. Nephrol., 11, 2231-2242.

Sezgin I, Koksal B, Bagci G, Kurtulgan HK and Ozdemir O (2011): CCR2 polymorphism in chronic renal failure patients requiring long term hemodialysis. Intern Med 50 (21): 2457-2461.

Tesch GH (2007): Role of macrophages in complications of type 2 diabetes. Clin Exp Pharmacol Physiol 34: 1016-1019. 
Vielhauer V, Anders HJ, Mack M, Cihak J, Strutz F, Stangassinger M, Luckow B, Grone HJ and Schlondorff D (2001): Obstructive nephropathy in the mouse: Progressive fibrosis correlates with tubulointerstitial chemokine expression and accumulation of CC chemokine receptor 2 and 5 positive leukocytes. J. Am. Soc. Nephrol., 12, 1173-1187.

Villeda SA, Luo J, Mosher KI, Zou B, Britschgi M, Bieri G, Stan TM, Fainberg N, Ding Z, Eggel A, Lucin KM, Czirr E, Park JS, Couillard-Després S, Aigner L,Li G, Peskind ER, Kaye JA, Quinn JF, Galasko DR, Xie XS, Rando TA and Wyss-Coray T (2011): The ageing systemic milieu negatively regulates neurogenesis and cognitive function. Nature 477(7362):90-94.

Wada T, Yokoyama H, Su SB, Mukaida N, Iwano M, Dohi K, Takahashi Y, Sasaki T, Furuichi K, Segawa C, Hisada Y, Ohta S, Takasawa K, Kobayashi $K$ and Matsushima K (1996): Monitoring urinary levels of monocyte chemotactic and activating factor reflects disease activity of lupus nephritis. Kidney. Int., 49, 761-767.

$$
\begin{aligned}
& \text { الملخص العربي } \\
& \text { تعدد الأشكال الجينية لجين مستقبلات الكيموكين-r فى مرضى الفشل الكلوى المزمن المحتاجين }
\end{aligned}
$$

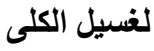

$$
\begin{aligned}
& \text { نسرين جمال الدين الهلباوى' ،خالد محمد الزرقانى"، أمير فتحى عبد العاطى" } \\
& \text { قسم 'الكيمياء الحيوية الطبية ، 'الباطنة العامة }
\end{aligned}
$$

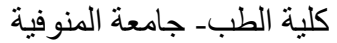

